\title{
Inhibitory effect of Koreinsis chinensis leaves extract on proinflammatory responses in lipopolysaccharide-induced Raw 264.7 cells
}

\author{
Young-Je Cho ${ }^{1}$
}

Lipopolysaccharide로 유도된 Raw 264.7 cell에서 잣 잎
(Koreinsis chinensis L.) 추출물의 Pro-inflammatory 억제 효과

조 영 제 ${ }^{1}$

Received: 3 March 2017 / Accepted: 30 March 2017 / Published Online: 30 September 2017

(C) The Korean Society for Applied Biological Chemistry 2017

\begin{abstract}
Hyaluronidase inhibitory activity as inflammatory factor of Koreinsis chinensis leaf ethanol extract was showed higher inhibitory activity than water extract. $29.5 \%$ inhibitory activity was shown at concentration of $200 \mu \mathrm{g} / \mathrm{mL}$ phenolics. Lipopolysaccharide (LPS)-stimulated Raw 264.7 cells were treated with different concentrations $(5-25 \mu \mathrm{g} / \mathrm{mL})$ of Koreinsis chinensis leaf extract and the amount of nitric oxide (NO) was determined; LPS-treated cells produced 3 times more NO than non-LPS treated cells. Moreover, the NO production in cells treated with Koreinsis chinensis leaf extract showed inhibitory effect in a concentration-dependent manner. Due to the stimulantinduced NO production is regulated by the inducible nitric oxide synthase (iNOS), we determined the iNOS protein level to elucidate the mechanism by which the NO production was inhibited. It was reduced by $40 \%$ with a Koreinsis chinensis leaf extract concentration of $25 \mu \mathrm{g} / \mathrm{mL}$ and identified iNOS inhibition in dose-dependent manner. The prostaglandin $\mathrm{E}_{2}$ production in cells treated with Koreinsis chinensis leaf extract was reduced by $26.2 \%$ at concentration of $25 \mu \mathrm{g} / \mathrm{mL}$. The protein expression of

Young-Je Cho $(\bowtie)$

E-mail: yjcho@knu.ac.kr

${ }^{1}$ School of Food science \& Biotechnology/Food \& Bio-Industry Research Institute, Kyungpook National University, 80 University Street, Bukgu, Daegu 41566, Republic of Korea

This is an Open Access article distributed under the terms of the Creative Commons Attribution Non-Commercial License (http://creativecommons. org/licenses/by-nc/3.0/) which permits unrestricted non-commercial use, distribution, and reproduction in any medium, provided the original work is properly cited.
\end{abstract}

cyclooxygenase-2 in LPS-treated Raw 264.7 cells was inhibited by $64 \%$ at $25 \mu \mathrm{g} / \mathrm{mL}$ of Koreinsis chinensis leaf extract. Koreinsis chinensis leaf extract had a concentration-dependent inhibitory effect on the production of tumor necrosis factor- $\alpha$ and interleukin6 as pro-inflammatory cytokine in LPS-treated Raw 264.7 cells at $25 \mu \mathrm{g} / \mathrm{mL}$ of Koreinsis chinensis leaf extract. Their levels were decreased by 61.7 and $62 \%$ respectively.

Keywords Antiinflammation · Extracts · Hyaluronidase inhibition $\cdot$ Koreinsis chinensis leaf

\section{서 론}

최근 생리활성물질들의 연구경향은 다양한 자원으로부터 질병 의 예방 혹은 치료 효과를 가지는 천연물에 대해 연구되고 있 으며, 건강한 삶을 지향하는 인류의 요구에 따라 다양한 생리 기능 물질에 대한 탐색 연구 중 특히 식물자원에 포함된 phytochemical에 대한 많은 연구가 진행되고 있다(Bunney 1992; Cho 등, 2005; Cho와 An 2008). 현재까지 많은 식물소재들의 건강증진효능 및 질병예방 효과가 밝혀지면서, 생체방어와 건강 개선 등을 위한 기능성식품으로서 활용되기 위한 생리기능이 요 구되고 있으며 이런 식품을 기능성 식품이라고 한다(Park 등, 2004).

생체의 면역기구로 골수에서 생산되는 탐식세포인 macrophage 는 체내에 들어온 이물질을 세포독성물질을 분비하여 이종세포 나 암세포를 파괴하는 면역세포인데, 미량의 그람 음성균의 외 막 구성성분인 lipopolysaccharide에 의해 활성화되어 cytokine, 
활성산소, nitric oxide $(\mathrm{NO})$ 등을 생산, 방출하게 된다(Oshima 와 Bartsch 1994; Gross와 Wolin 1995; Kroncke 등, 1998). 특히, 대식세포에서 lipopolysaccharide와 같은 자극에 의해 염 증 반응의 전사인자인 nuclear factor- $\mathrm{\kappa B}$ 를 활성화시켜 inducible nitric oxide synthase (iNOS)와 cyclooxygenase-2 단백질을 발 현시켜 과량의 $\mathrm{NO}$ 와 prostaglandin $\mathrm{E}_{2}$ 를 생성하여 염증을 일으 킨다(Stuehr 1999; So 등, 2004; Nirupama 등, 2005). 이때 interleukin-1 $\beta$, IL-6 그리고 tumor necrosis factor와 같은 proinflammatory cytokine을 분비하여 염증반응에도 관여하게 된 다(Naoko 등, 2005; Nirupama 등, 2005).

잣나무(Pinus koraiensis Siebold et Zucc)는 소나무과에 속하 는 상록교목으로, Lee 등(2003)은 잣나무에 함유된 천연물로 5hydroxy-7-methoxyflavone, chrysin, pinocembrin, galangin, pinosylvin, 3-hydroxy-5-methoxystilbene 등을 보고하였고, Bae 등(2003)과 Cuyckens와Claeys (2004)는 잣나무 잎의 성분으로 는 gallic acid, protocatechuic acid, vanillic acid, syringic acid, $p$-coumaric acid, scopoletin, (+)-catechin 등의 물질을 분리 동 정하였다. 또한 $\mathrm{Kim}$ 등(2010)은 잣나무 잎에 존재하는 항균물 질이 astragalin과 juglanin임을 보고하였다. 잣나무잎의 생리활 성에 관한 연구로는 잣잎의 에틸아세테이트 분획물이 피부상재 균인 P. acnes, S. aureus, P. ovale 및 E. coli 등에 항균활성 을 나타내었으며, 아글리콘 분획물은 높은 항산화효과를 나타내 었다는 보고가 있다(Kim 등, 2010).

따라서 본 연구에서는 국내에서 발생되어 수확되지 않고 방 치되어 버려지는 임산폐자원인 잣나무(Pinus koraiensis) 잎 추 출물에서 염증억제효과를 가지는 물질이 있음을 확인하고, 추출 물의 염증 억제 효과를 macrophage cell 라인인 Raw cell을 이 용하여 항염증 효과를 검정하기 위하여 세포내의 단백질의 변 화를 Western blotting을 통하여 $\mathrm{NO}, \mathrm{PGE}_{2}, \mathrm{iNOS}, \mathrm{COX}-2$ 등 의 protein expression억제효과와 proinflammatory cytokine의 억제 효과를 확인하여 약리성 식품 소재(medicinal food resources) 로 활용하고자 하였다.

\section{재료 및 방법}

시료

본 실험에 사용된 시료는 경북 영천지역에서 재배되고 있는 잣 나무로부터 2015년에 채취하여 $45^{\circ} \mathrm{C}$ dry oven에서 건조한 후 40 mesh 분말로 만들어 $4{ }^{\circ} \mathrm{C}$ 냉장 보관하며 시료로 사용하였다.

\section{시료 추출물의 제조}

시료 추출물의 제조는 물 추출물의 경우 시료 $1 \mathrm{~g}$ 에 증류수 200 $\mathrm{mL}$ 을 넣고 액이 $100 \mathrm{~mL}$ 이 될 때까지 가열한 후 냉각하였다. 에탄올 추출물은 시료 $1 \mathrm{~g}$ 에 $100 \mathrm{~mL}$ 의 $60 \%$ ethanol을 가하고 homogeniger로 $20,000 \mathrm{rpm}$ 에서 1 분간 균질화 시킨 후 24 시간 동안 교반 추출하였다. 추출액은 whatman No. 1 filter paper로 여과한 후 필요에 따라 rotary vacuum evaporator (Eyela NE, Tokyo, Japan)에서 농축하여 시료로 사용하였다.

\section{Hyaluronidase 저해 활성 측정}

Hyaluronidase 저해활성 측정은 sodium-hyaluronic acid (HA)로
부터 형성된 N-acetylglucosamine을 glucoxazoline 유도체로 변 형시킨 후 $p$-dimethylamino benzaldehyde (DMAB)로 발색시켜 흡광도를 측정하여 효소 활성을 측정하였다(Dorfman과 $\mathrm{Ott}$ 1948; Moon 등, 1999). 0.1 M acetate buffer ( $\mathrm{pH}$ 3.5)에 녹인 hyaluronidase $(7,900 \mathrm{unit} / \mathrm{mL}) \quad 0.05 \mathrm{~mL}$ 와 시료용액 $0.1 \mathrm{~mL}$ 를 혼합하여 $37^{\circ} \mathrm{C}$ 에서 20 분간 배양하였다. 배양 후 $12.5 \mathrm{mM}$ $\mathrm{CaCl}_{2} \quad 0.1 \mathrm{~mL}$ 를 가하고 혼합 후 다시 20 분간 배양하였다. 기질 로서 $0.1 \mathrm{M}$ acetate buffer $(\mathrm{pH} 3.5)$ 에 녹인 $\mathrm{HA}(12 \mathrm{mg} / \mathrm{mL})$ 를 첨가하여 다시 40 분간 배양하였다. 배양 후 반응혼합물에 $0.4 \mathrm{~N}$ potassiumtetraborate $0.1 \mathrm{~mL}$ 와 $0.4 \mathrm{~N} \mathrm{NaOH} \quad 0.1 \mathrm{~mL}$ 를 첨가하고 3 분동안 water bath에서 가열한 후 냉각시켰다. 냉각 시킨 반응물에 발색제로 $\mathrm{DMAB}$ 시약 $3 \mathrm{~mL}$ 을 가하여 $37^{\circ} \mathrm{C}$ 에 서 20 분간 발색시켰다. 발색 후 $585 \mathrm{~nm}$ 에서 흡광도를 측정하여 저해율 $(\%)$ 은 (1-시료첨가군의 흡광도/무첨가군의 흡광도 $) \times 100$ 으 로 표시하였다.

\section{항염증 효과 측정을 위한 세포배양}

Murine macrophage cell line인 Raw 264.7 cells은 한국세포주 은행 (Korean Cell Line Research Foundation)에서 구입하였다. 세포배양은 10\% fetal bovine serum (HyClone, GE Healthcare Life Science, Chicago, IL, USA), $100 \mathrm{U} / \mathrm{mL}$ penicillin 및 $100 \mu \mathrm{g} / \mathrm{mL}$ streptomycin을 혼합한 배지를 사용한 Dulbecco's modified Eagle's medium으로 $37^{\circ} \mathrm{C}, 5 \% \mathrm{CO}_{2}$ incubator에서 72 시간 배양하였다. Cell 배양 dish에 cell의 밀도가 $23 \times 10^{6} / \mathrm{mL}$ 정도가 되게 계대 배양하여 $5 \% \mathrm{CO}_{2}$ 조건으로 cell 상태를 유 지하였다. 실험을 할 때는, $80 \%$ 의 confluency와 20 회 이하 passages 조건을 준수하여 실험 시, 실험 전 12시간은 $\mathrm{FBS}$ 를 제거한 배지로 cell를 배양시켰다(Syu-ichi 등, 2005).

\section{MTT assay에 의한 cell toxicity 측정}

세포 독성 측정은 Carmichael (1987)의 방법에 따라 측정하였 다. Raw 264.7 세포를 96 well plate에 $5 \times 10^{4}$ cells $/ \mathrm{mL}$ 가 되게 $0.18 \mathrm{~mL}$ 분주하고, 시료를 농도별로 조제하여 $0.02 \mathrm{~mL}$ 첨가한 후 $37{ }^{\circ} \mathrm{C}, 5 \% \quad \mathrm{CO}_{2}$ incubator에서 24시간 배양하였다. 여기에 $5 \mathrm{mg} / \mathrm{mL}$ 농도로 제조한 $\mathrm{MTT}$ 용액 $0.02 \mathrm{~mL}$ 를 첨가하여 4시 간 배양한 후 배양액을 제거하였다. 배양액을 제거한 뒤 각 well에 dimethyl sulfoxide $0.15 \mathrm{~mL}$ 를 가하여 실온에서 30 분간 반응 시킨 뒤 enzyme-linked immunosorbent assay reader로 $540 \mathrm{~nm}$ 에서 흡광도를 측정하였다. 세포 독성 측정은 시료 용액 의 첨가군과 무첨가군의 흡광도 감소율로 나타내었다. 대조군은 시료와 동일한 양의 증류수를 첨가하여 동일한 조건으로 배양 하였으며, Cell viability $(\%)$ 는 (1-대조구의 흡광도/시료첨가군의 흡광도 $) \times 100$ 으로 표시하였다.

\section{Nitric Oxide 측정}

$\mathrm{NO}$ 측정은 cell의 supernatant에서의 $\mathrm{NO}$ 의 량을 nitrite and nitrate로서 측정을 하였다. Nitrite에 대한 nitrate로 환원된 후의 안전한 형태는 griess reagent (Sigma, USA)를 사용하였다. 6 well plate에 $2 \times 10^{6}$ 개의 cell을 confluence가 $80 \%$ 일 때, phosphate buffered saline (PBS)로 2번 washing한 후에 무혈청 배지를 사용하여 12시간 이상 배양시킨 후에 lipopolysaccharide (LPS) $10 \mathrm{ng} / \mathrm{mL}$ 를 control 군을 뺀 모든 well에다 넣어서 자극 
시켰다. 2시간 후에 시료를 $5,100 \mu \mathrm{g} / \mathrm{mL}$ 의 농도로 처리하여 실 험하였다. NO 생성량은 시간별로 supernatant를 모아 griess reagent로 10 분간 차광시켜 반응시킨 후에 $540 \mathrm{~nm}$ 에서 흡광도 로 측정하였다. 저해율은 (1-시료첨가군의 흡광도/대조군의 흡 광도 $) \times 100$ 으로 나타내었다.

\section{Western blotting에 의한 iNOS와 COX-2 단백질 발현 측정}

Raw 264.7 세포는 $100 \mathrm{~mm}$ tissue culture dish에 cell seeding 한 후 24시간 동안 배양하여 cell을 안정화 시켰다. 배지를 제 거한 후 추출물을 농도별로 처리한 배지로 24-48시간 배양한 후 다시 배지를 제거하고 PBS로 2번 세척해주었다. Radioimmunoprecipitation assay buffer $10 \mathrm{~mL}$ 에 complete mini 1 tab를 가 하여 $100 \mathrm{~mL} / \mathrm{mL}$ 로 용해해서 $4{ }^{\circ} \mathrm{C}, 12,000 \mathrm{rpm}$ 에서 20 분간 원 심 분리 하였다. 원심 분리하여 얻은 상층액은 Bradford assay 로 정량하여 $30 \mu \mathrm{L}$ 의 단백질을 $10 \%$ 의 sodium dodecyl sulfatepolyacrylamide gel electrophoresis를 이용하여 전기 영동하여 분리 하였다. 분리된 단백질은 semi dry transfer cell 기기 (Millipore Corp, Billerica, MA, USA)를 이용하여 polyvinylidene fluoride membrance에 옮긴 다음 실온에서 1시간 blocking buffer $(5 \%$ skin milk in tris-buffered saline and tween 20)에 서 incubation 시켰다. Primary antibody를 희석하여 $4{ }^{\circ} \mathrm{C}$ 에서 over night한 다음, 다시 10 분 간격으로 blocking buffer로 3 회 washing하고 mouse anti-rabbit IgG HPR, bovine anti-goat $\mathrm{IgG} \mathrm{HRP}$ 의 각각의 secondary antibody를 $1: 1,000$ 로 희석하여 상온에서 2시간 동안 배양하였다. 3회 washing한 뒤 Enhanced chemiluminescence kit (Millipore, Bedford, MA, USA)와 반 응시켜 X-ray film에 노출 시켰다. LAS 4,000 image analyzer (Fujifilm Life Science, Tokyo, Japan)을 이용하여 밴드 현상 및 정량 하였다.

\section{사이토카인 생성량 측정}

대식세포를 배양하여 6-well에 cells $\left(1 \times 10^{6} / \mathrm{mL}\right)$ 을 분주하고 agonist (세포 자극제)를 농도별 또는 시간별로 처리하였다. 1시 간 후에 LPS $(1 \mu \mathrm{g} / \mathrm{mL})$ 를 처리하고, LPS 처리 후 24시간 동 안 시간대 별로 세포 배양액을 취하여 cytokine을 측정하였다. 수거된 배지는 측정 전까지 $-70{ }^{\circ} \mathrm{C}$ 에서 보관하며, $\mathrm{TNF}-\alpha$, IL$6, \mathrm{PGE}_{2}$ 등의 함량을 enzyme immuno assay kit를 사용하여 측정하였다. 각 cytokine의 함량은 표준물질의 반응으로부터 얻 어진 표준곡선을 이용하여 환산하였다.

\section{통계처리}

모든 실험은 3회 반복 실시하였으며 실험결과는 평균 \pm 표준오 차로 표기하였다. 분석에 영향을 미치는 모든 변수들은 SAS program (SAS Institute, Cary, NC, USA)을 이용하여 통계 처 리 하였다(Statistical Analysis System Institute 2001).

\section{결과 및 고찰}

\section{잣잎 추출물의 hyaluronidase 억제 효과}

피부의 epidermis와 dermis에 있어서 주요한 세포외 matrix인 $\mathrm{HA}$ 는 glucuronic acid과 glucosamine으로 구성된 고분자의 점

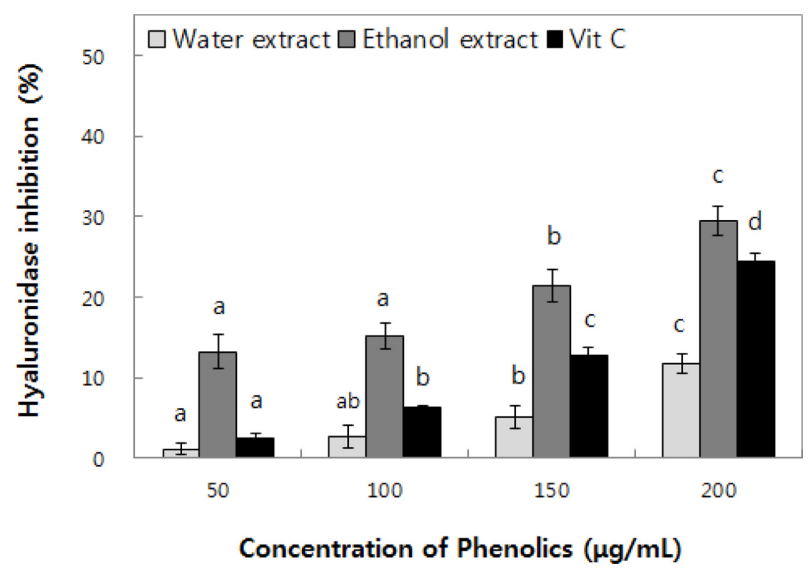

Fig. 1 Inhibitory activity of water and ethanol extracts from Pinus koraiensis leaves on hyaluronidase. The data were expressed as the mean \pm standard deviation $(n=6),{ }^{\mathrm{a}-\mathrm{d}}$ Means with the different letter on bars are significantly different at $p<0.05$ by a Duncan's multiple range tests

액성 mucopolysaccharide이다. $\mathrm{HA}$ 물질 중에서 고분자 $\mathrm{HA}$ 는 macrophage의 식세포로서의 기능을 저해시키고, 저분자 $\mathrm{HA}$ 는 inflammation을 증가시킨다고 알려져 있다(Park 등, 2011). 따라 서 hyaluronidase의 활성 억제를 유도함으로서 고분자의 HA 형 태를 유지시켜 염증억제 효과를 기대할 수 있다(Ghosh 1994).

염증 형성의 중요 요소인 HAase 저해효과를 측정한 결과 Fig. 1에서와 같이 물 추출물에서는 $50-200 \mu \mathrm{g} / \mathrm{mL}$ phenolic 농 도에서 1.1-11.7\%의 저해효과를 나타내었으며, ethanol 추출물 $50-200 \mu \mathrm{g} / \mathrm{mL}$ phenolic 농도에서 13.2-29.5\%의 저해효과를 나 타내어 ethanol 추출물에서 상대적으로 더 높은 HAase 저해효 과를 보여주었다. 식물소재 중에서 오가피, 우슬, 석창포, 당귀, 해동피, 갈근, 복분자 등의 추출물에서 $10 \%$ 정도의 HAase저해 활성을 보고한 문헌(Lee 2001)과 비교하면 잣잎 추출물의 항염 증 활성이 더 우수함을 확인할 수 있었다. 따라서 잣잎 추출물 은 염증 유발 요소인 HAase 저해로 인한 항염증, 아토피 억제 효과를 활용하는 제품에 적용할 수 있을 것이라 판단되었다.

\section{MTT assay에 의한 cell viability}

Cell viability를 측정하기 위하여 MTT assay를 이용하여 Raw 264.7 세포에서 잣나무 잎 물 추출물과 ethanol 추출물을 농도별 로 $(5,10,25,50 \mu \mathrm{g} / \mathrm{mL})$ 처리하여 세포독성을 확인 한 결과 Fig. 2에서와 같이 물 추출물과 ethanol 추출물 모두 $25 \mu \mathrm{g} / \mathrm{mL}$ 까 지의 농도에서는 $90 \%$ 이상의 세포 생존율을 나타내었고, 물과 ethanol 추출물 $50 \mu \mathrm{g} / \mathrm{mL}$ 처리군에서 각각 $82,73 \%$ 의 cell viability를 나타내어 $50 \mu \mathrm{g} / \mathrm{mL}$ 이상의 농도에서는 세포 독성을 나타낼 확률이 높게 나타났다. 따라서 잣나무 잎 물 추출물과 ethanol 추출물은 $25 \mu \mathrm{g} / \mathrm{mL}$ 이하의 농도에서는 세포독성이 낮아 세포의 생존률에 영향을 주지 않는다는 사실을 알 수 있었다. 이 상의 결과로 $\mathrm{NO}$, cytokine 및 western blot은 $90 \%$ 이상의 생존 률을 가지는 $25 \mu \mathrm{g} / \mathrm{mL}$ 이하의 농도에서 실험을 진행하였다.

잣나무 잎 추출물이 Raw cell에서 NO 생산에 미치는 영향 LPS는 그람 음성균의 외막 구성성분이며, macrophage는 LPS에 

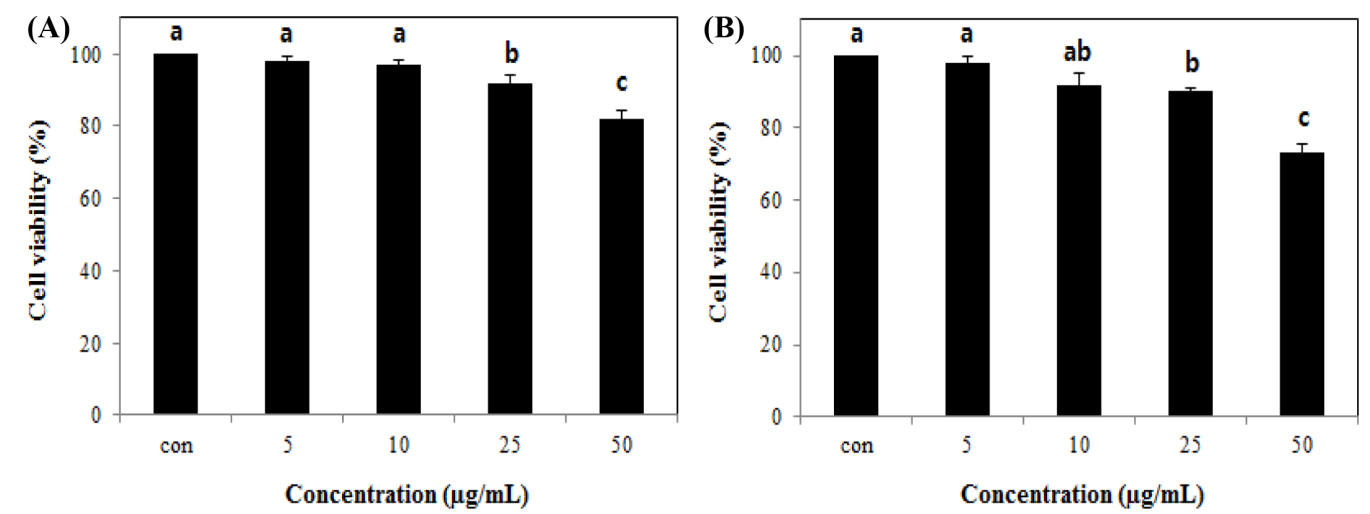

Fig. 2 Cell viability of Pinus koraiensis leaves extracts on macrophage (Raw 264.7). (A): Water extracts, (B): Ethanol extracts. ${ }^{\text {a-c }}$ Means with the different letter on bars are significantly different at $p<0.05$ by a Duncan's multiple range tests
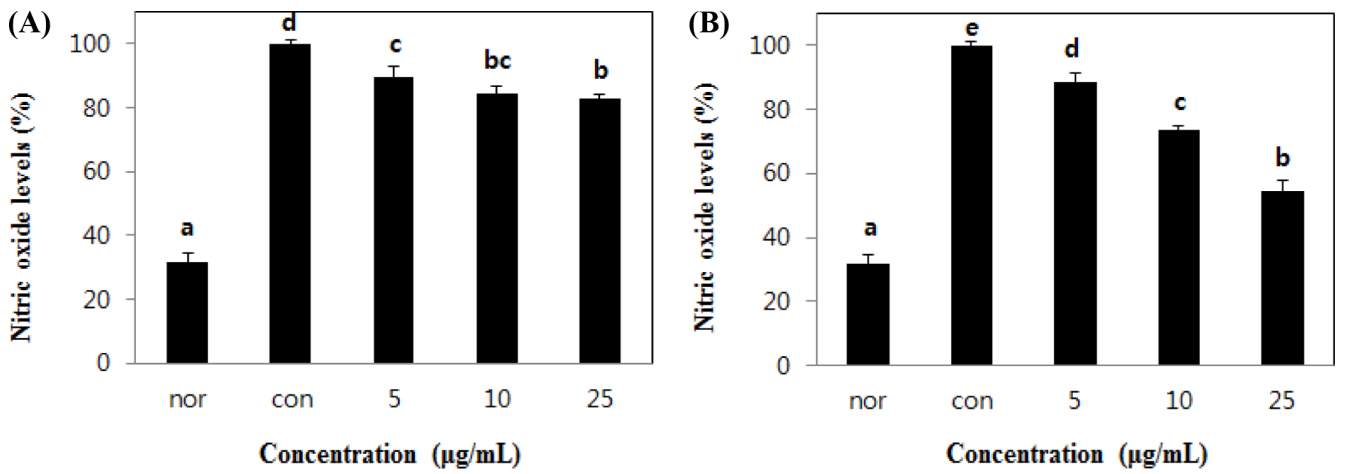

Fig. 3 Effects of extracts from Pinus koraiensis leaves on the production of NO in Raw 264.7 cells. Raw 264.7 cells were treated with 10 or $100 \mu \mathrm{g} / \mathrm{mL}$ concentrations of extracts from Pinus koraiensis leaves dissolved in DW for $1 \mathrm{~h}$ prior to the addition of LPS (10 ng/mL), and the cells were further incubated for $24 \mathrm{~h}$. Control cells were incubated with vehicle alone. The concentrations of nitrite and nitrate in culture medium were monitored as described in the experimental procedures. Data represent the mean \pm SD with nine separate experiments. LPS: 10 ng/mL LPS treatment. (A): Water extracts, (B): Ethanol extracts. ${ }^{\mathrm{a}-\mathrm{e}}$ Means with the different letter on bars are significantly different at $p<0.05$ by a Duncan's multiple range tests
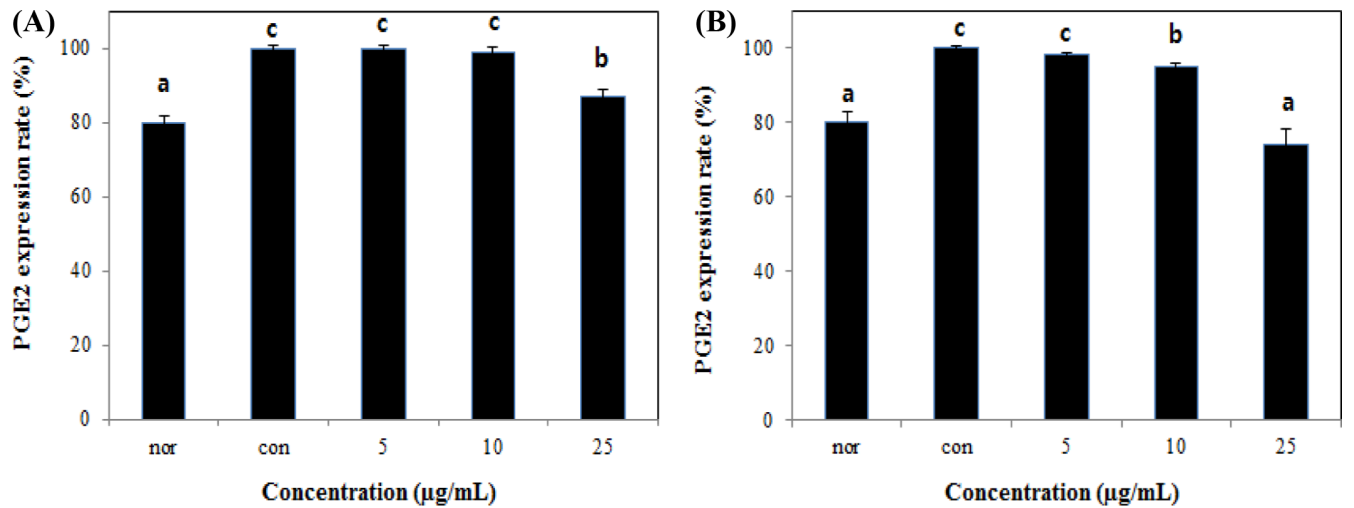

Fig. 4 Inhibition rate of Pinus koraiensis leaves extracts on $\mathrm{PGE}_{2}$. Raw 264.7 cells were incubated with various concentrations (5, 10 and $\left.50 \mu \mathrm{g} / \mathrm{mL}\right)$ of Pinus koraiensis leaves extracts for $1 \mathrm{~h}$ and then treated with $1 \mu \mathrm{g} / \mathrm{mL}$ of LPS for $24 \mathrm{~h}$. (A): Water extracts, (B): Ethanol extracts. ${ }^{\mathrm{a}-\mathrm{c}} \mathrm{Means}$ with the different letter on bars are significantly different at $p<0.05$ by a Duncan's multiple range tests

의해 activation 되어 다양한 cytokine, ROS, $\mathrm{NO}$ 등을 생산, 방출한다. $\mathrm{NO}$ 는 nitric oxide synthase $(\mathrm{NOS})$ 에 의해 만들어지 며, NOS는 endothelial NOS 및 neuronal NOS와 염증성 인자 인 inducible NOS로 분류할 수 있다. 이러한 NOS들은 Larginine을 L-citrulline으로 전환시키면서 $\mathrm{NO}$ 를 형성하게 되는데,
일반적으로 $\mathrm{NO}$ 의 생성은 외부에서 침입한 박테리아를 죽이거 나 종양을 제거시키는 등 중요한 역할을 수행하지만 병리학적 인 원인으로 인해 과도한 $\mathrm{NO}$ 가 생성되게 되면 염증을 유발시 키고, 조직의 손상, 유전자 변이 및 신경 손상 등을 유발하게 된다(Kim 등, 2006). 

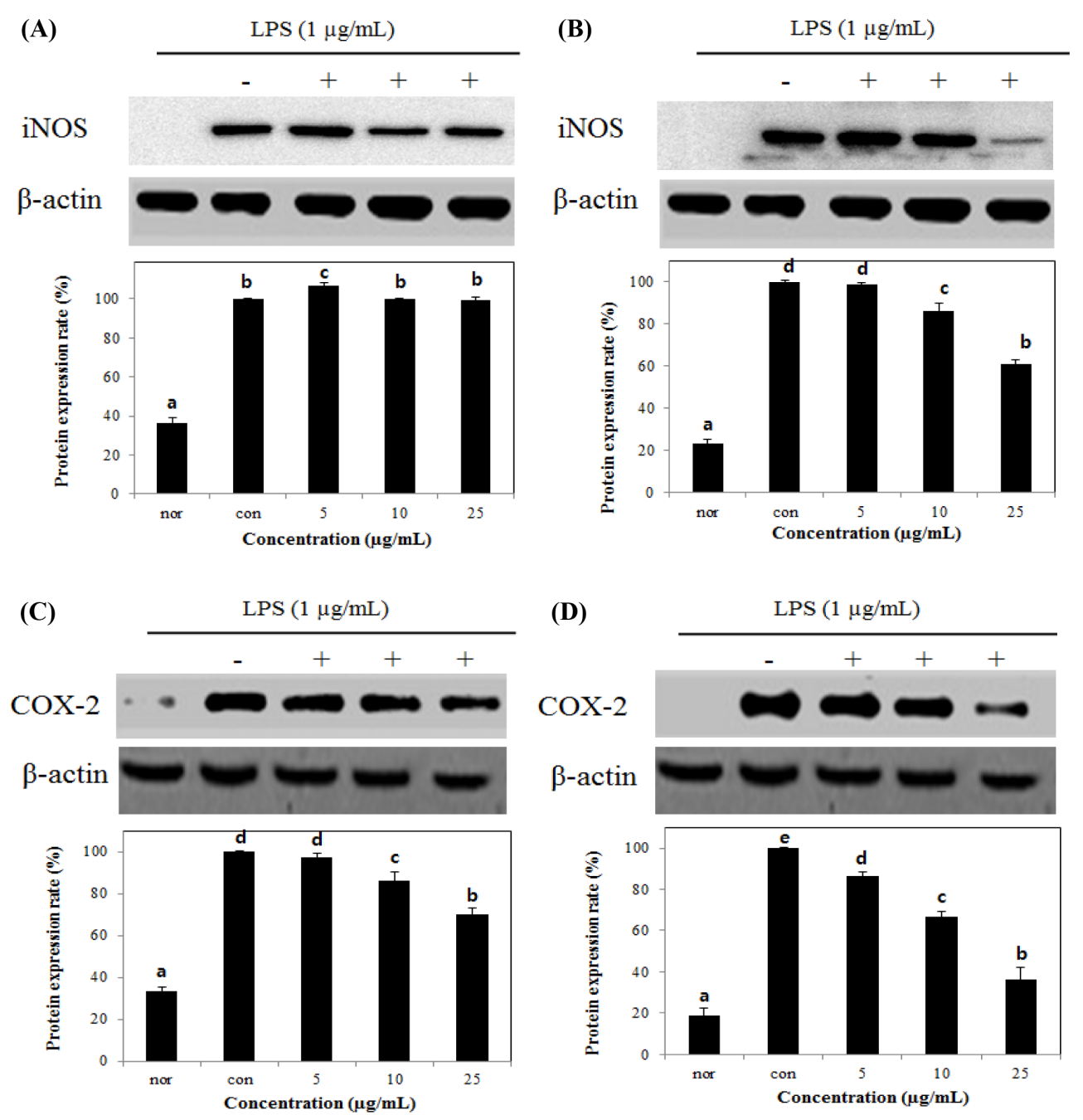

Fig. 5 Effects of extracts from Pinus koraiensis leaves the production of iNOS and COX-2 protein expression in LPS stimulated Raw 264.7 cells. Raw 264.7 cells were treated with 10 and $100 \mu \mathrm{g} / \mathrm{mL}$ concentrations of extracts from Pinus koraiensis leaves dissolved in DW for $1 \mathrm{~h}$ prior to the addition of LPS $(10 \mathrm{ng} / \mathrm{mL})$, and the cells were further incubated for $24 \mathrm{~h}$. Control cells were incubated with vehicle alone. The concentrations of nitrite and nitrate in culture medium were monitored as described in the experimental procedures. Data represent the mean $\pm \mathrm{SD}$ with nine separate experiments. Histogram show the densitometric of iNOS protein normalized to GAPDH. LPS: $10 \mathrm{ng} / \mathrm{mL}$ treatment. (A,C): Water extracts, (B,D): Ethanol extracts. ${ }^{\mathrm{a}}{ }^{-}$ ${ }^{\mathrm{d}}$ Means with the different letter on bars are significantly different at $p<0.05$ by a Duncan's multiple range tests

Raw 264.7 cell에서의 NO 생성억제 정도를 측정하기 위하여 잣나무잎 추출물을 농도별로 세포에 처리하여 생성되는 $\mathrm{NO}$ 량 을 측정한 결과는 Fig. 3에서와 같이 LPS처리군은 LPS 무처리 군에 비하여 3 배에 가까운 $\mathrm{NO}$ 발현을 나타내었으며, 물 추출물 과 ethanol 추출물 모두 농도 의존적으로 $\mathrm{NO}$ 발현을 억제하는 양상을 나타내었다. 물 추출물에 비해 ethanol 추출물에서 상대 적으로 더 높은 $\mathrm{NO}$ 발현 억제를 나타내었으며, $25 \mu \mathrm{g} / \mathrm{mL}$ 의 처 리농도에서 잣나무 잎 ethanol 추출물은 $46 \%$ 정도의 억제 효 과를 나타내었다.

잣나무 잎 추출물이 Raw cell의 prostagrandin E-2 (PGE 생성에 미치는 영향

체내에서 염증의 발생과정에서 과량의 $\mathrm{NO}$ 및 prostaglandin $\mathrm{E}_{2}$ 등의 염증성인자가 inducible NO synthase 및 cycloxygenase-2
등의 작용에 의해 발현되게 된다. Prostaglandin은 국소적으로 활성화되는 물질로서 염증반응을 유도하는 중요한 인자로 arachidonic acid로부터 cyclooxygenase $(\mathrm{COX})$ 의 작용에 의해 합성되어 진다. 따라서 잣나무잎 추출물이 Raw 264.7 세포에서 $\mathrm{LPS}$ 에 의해서 생성된 $\mathrm{PGE}_{2}$ 의 생성억제 효과를 측정하였다. 그 결과 Fig. 4에서와 같이 $25 \mu \mathrm{g} / \mathrm{mL}$ 의 처리농도에서 물 추출물이 $13.1 \%$, ethanol 추출물이 $26.2 \%$ 의 저해율을 나타내었다. Yoon 등(2007)은 쑥 추출물이 $50 \mu \mathrm{g} / \mathrm{mL}$ 의 농도에서 $\mathrm{PGE}_{2}$ 의 생성이 저해되는 것을 보고하였다.

잣나무잎 추출물이 LPS로 염증 유도된 Raw cell의 iNOS와 COX-2 발현에 미치는 영향

$\mathrm{NO}$ 는 항암 및 항균 작용뿐만 아니라 다양한 염증성 질환의 발 병에도 관여한다. 그러나 과도한 $\mathrm{NO}$ 가 발현되게 되면 염증 반 

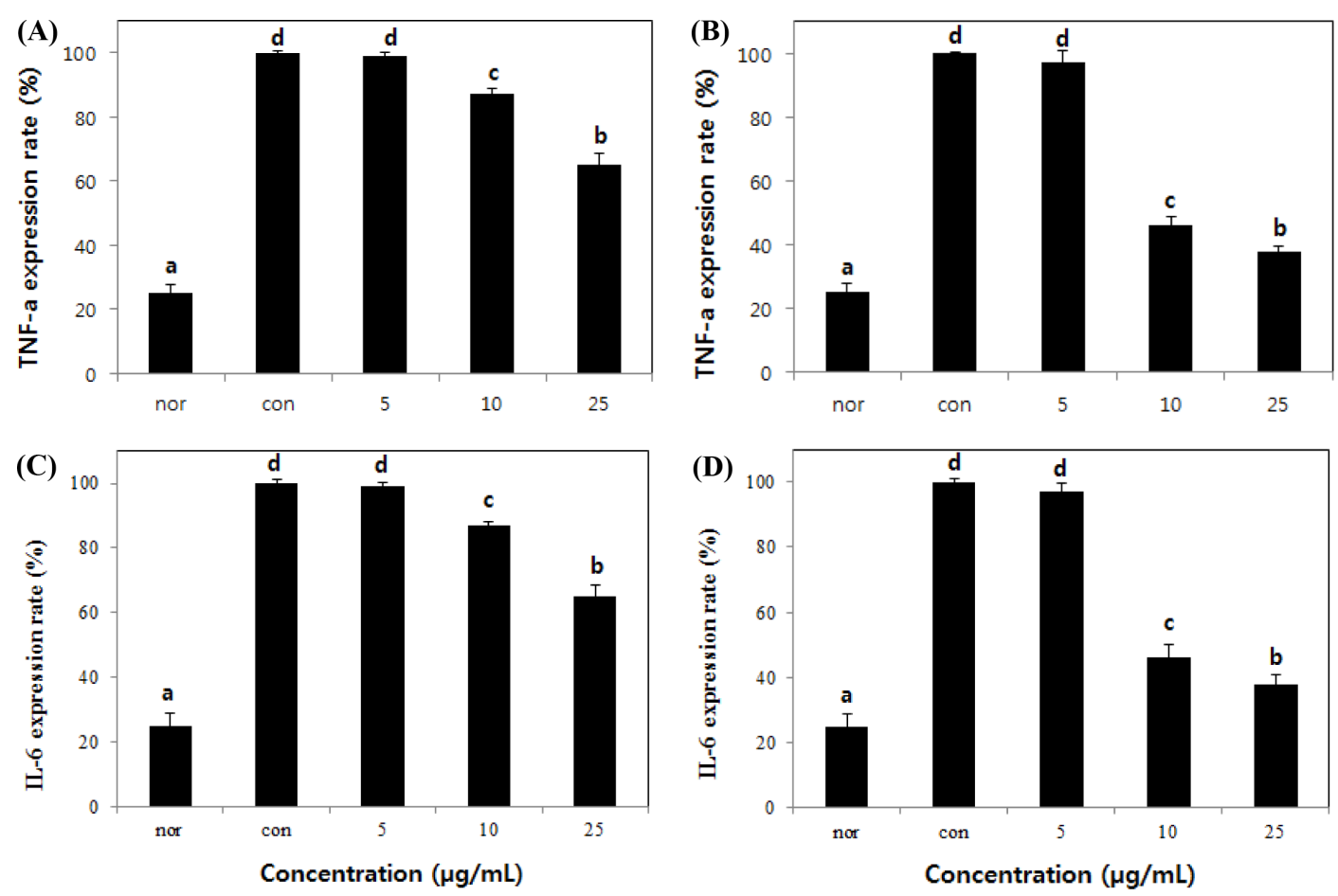

Fig. 6 Inhibition rate of Pinus koraiensis leaves extracts on pro-inflammatory cytokine. Raw 264.7 cells were incubated with various concentrations (5, 10, and $50 \mu \mathrm{g} / \mathrm{mL}$ ) of Pinus koraiensis leaves extracts for $1 \mathrm{~h}$ and then treated with $1 \mu \mathrm{g} / \mathrm{mL}$ of LPS for $24 \mathrm{~h}$. A: TNF- $\alpha$, B: IL-1 $\beta$, C: IL-6, D: IL-8. $(\mathrm{A}, \mathrm{C})$ : Water extracts, $(\mathrm{B}, \mathrm{D})$ : Ethanol extracts. ${ }^{\mathrm{a}-\mathrm{d}}$ Means with the different letter on bars are significantly different at $p<0.05$ by a Duncan's multiple range tests

응이 심화되고, 상처 치유의 억제 등의 원인으로서 작용하며, 면역기능의 저하 및 세포를 죽게 만드는 원인이 된다. $\mathrm{NO}$ 는 $\mathrm{NO}$ synthase (NOS)의 작용에 의해 만들어 지게 되는데 NOS 중 자극에 유도된 iNOS의 경우, 오랜 기간 동안 다량의 $\mathrm{NO}$ 를 생성하게 되고, 과량으로 생성된 $\mathrm{NO}$ 는 주위 조직에 세포독성 을 나타낸다. 즉 LPS 자극에 의해 유도되어진 Raw 264.7 cell 에서 iNOS protein expression의 감소는 항염증 효과를 기대할 수 있게 한다. 즉, $\mathrm{iNOS}$ 는 바이러스를 포함하는 전염성 병원체 에 대하여 방어 역할을 수행하며, 염증 질환, 순환계 질환 및 암과 밀접한 관련이 있는 것으로 알려져 있다.

$\mathrm{NO}$ 생성 억제기작에 관한 iNOS 단백질의 관련성을 조사하 기 위하여 immunoblot analysis를 이용하여 western blot으로 세포질 내에서의 iNOS protein expression을 측정한 결과 Fig. $5-\mathrm{A}$ 와 $\mathrm{B}$ 에서와 같이, 잣잎 물 추출물의 경우 $5-25 \mu \mathrm{g} / \mathrm{mL}$ 의 농 도 범위에서 iNOS protein 발현 억제가 거의 발생하지 않았으 며, ethanol 추출물의 경우 첨가 농도의존적으로 iNOS protein 발현이 감소하는 경향을 관찰 할 수 있었으며 $50 \mu \mathrm{g} / \mathrm{mL}$ 의 처 리농도에서 $40 \%$ 의 억제 효과를 나타내었다. Salidroside 추출물 이 $\mathrm{iNOS}$ 저해 활성 측정에서 $30 \%$ 의 활성을 나타내었다는 Won 등(2008)의 보고보다 잣나무잎 ethanol 추출물이 저해 효 과가 높았다. 따라서 잣잎 ethanol 추출물은 LPS에 의해 유도 된 iNOS protein의 전사를 저해하여 염증반응 억제를 유도하는 물질임을 확인 할 수 있었다.

Prooxidant나 pro-inflammatory 자극제에 의해 MEKK-1, $\mathrm{NF}-\kappa \mathrm{B}$ 의 활성화를 통해 생성되는 $\mathrm{COX}-2$ 는 염증반응에 있어서 prostaglandin 합성을 증가시켜 염증억제 작용을 수행하는 중추 적 역할을 한다. 또한 COX-2의 발현은 proinflammatory agent 인 IL- $1 \beta, \mathrm{TNF}-\alpha$ 와 phosphatidic acid 등에 의해서 증식하고, glucocorticioid와 IL-4, IL-1 $\beta$ 에 의해 발현억제가 유도된다. 그 러므로 COX-2의 inhibition agent의 개발은 염증의 치료제의 개 발에 있어서 target이 되고 있다. 따라서 macrophage에서 tumor necrosis factor-alpha, Interleukin-6와 같은 pro-inflammatory cytokine을 증가시키는 요인 중 하나인 COX-2의 protein expression 억제를 측정함으로써 항염증 효과를 확인할 수 있다.

본 실험에서 LPS 처리 시 또 다른 염증인자인 COX-2의 단 백질 발현을 측정한 결과 Fig. 5-C와 D에서와 같이 물 추출물 보다 ethanol 추출물에서 발현 억제 효과가 더 높은 것을 확인 할 수 있었고, 농도의존적으로 protein 발현 저해효과를 나타내 었다. Ethanol 추출물 $25 \mu \mathrm{g} / \mathrm{mL}$ 의 농도에서 COX-2 protein 발 현 억제가 $64 \%$ 의 억제효과를 나타내었다. 이는 Kaempferol-3O- $\beta$-D-sophoroside의 COX-2 저해효과를 측정한 결과 $20 \%$ 의 저해능을 나타내었다는 결과(Park 등, 2008) 보다 잣나무잎 추 출물이 더 높은 저해 효과를 나타내었다. 또한, Genistein의 COX-2의 억제효과와 비슷한 억제효과를 나타내었다(Park 등, 2007). Western blot 분석결과 잣나무잎 추출물은 LPS에 의해 유도된 COX-2 단백질 발현을 저해함으로써 염증반응 억제 효 과를 나타내는 것을 확인 할 수 있었다.

\section{잣나무잎 추출물의 cytokine 저해활성}

잣나무잎 추출물이 Raw 264.7 세포에서 LPS에 의해서 생성된 
pro-inflammatory cytokine의 형성을 억제하는지 알아보기 위하 여 TNF- $\alpha$, IL- 6 의 생성을 측정하였다. TNF- $\alpha$ 의 생성 억제는 Fig. 6-A와 B에서와 같이 물추출물에서 $5 \mu \mathrm{g} / \mathrm{mL}$ 의 저 농도에 서는 거의 효과를 나타내지 않았고, $10 \mu \mathrm{g} / \mathrm{mL}$ 이상의 농도에서 농도 의존적으로 억제 효과를 나타내었다. Ethanol 추출물의 경 우도 $10 \mu \mathrm{g} / \mathrm{mL}$ 이상의 농도에서 높은 저해 효과를 나타내었으 며, 10 과 $25 \mu \mathrm{g} / \mathrm{mL}$ 의 농도에서 53.3 과 $61.7 \%$ 의 저해효과를 나 타내었다. IL-6 생성 억제효과는 Fig. $6 \mathrm{C}$ 와 $\mathrm{D}$ 에서와 같이 저해 양상은 $\mathrm{TNF}-\alpha$ 의 저해 양상과 유사한 경향을 나타내었으며, Ethanol 추출물 $25 \mu \mathrm{g} / \mathrm{mL}$ 의 농도에서 $62 \%$ 의 높은 저해 효과를 나타내었다, Yoon 등(2007)은 쑥 추출물이 $50 \mu \mathrm{g} / \mathrm{mL}$ 의 농도에 서 LPS로 인한 TNF- $\alpha$, IL-1 $\beta$, IL-6와 같은 cytokine을 억제한 다고 보고하였으며, Cheon 등(2009)은 Blunesia sarmienti 열수 추출물이 LPS로 유도되어진 TNF- $\alpha$, IL- $1 \beta$, IL-6의 생성을 200 $\mu \mathrm{g} / \mathrm{mL}$ 의 농도에서 저해됨을 보고한 것에 비해 잣나무 잎 추출 물의 cytokine 저해활성이 더 우수하여 염증억제 효과가 있음을 확인하였다. 이러한 cytokine 측정 결과는 앞의 iNOS와 COX2 단백질의 발현 억제현상과 같은 유형을 나타내는 결과로 LPS 로 유도되어진 대식세포주인 Raw 264.7 세포에서 높은 염증반 응 억제 효과를 기대할 수 있었다. 따라서 잣나무 잎 ethanol 추출물은 염증억제를 위한 천연 기능성 소재로 활용이 가능할 것으로 판단되었다.

\section{초 록}

잣나무 잎 추출물에 대해 염증인자인 hyaluronidase 저해효과를 측정한 결과 ethanol 추출물에서 물추출물에 비해 상대적으로 더 높은 HAase 저해효과를 보여주었으며, $50-200 \mu \mathrm{g} / \mathrm{mL}$ phenolic 농도에서 13.2-29.5\%의 저해효과를 나타내었다. 잣나 무잎 추출물을 Raw 264.7 cell에 농도별로 처리하여 생성되는 $\mathrm{NO}$ 량을 측정한 결과 LPS처리군은 LPS 무처리군에 비하여 3 배에 가까운 $\mathrm{NO}$ 발현을 나타내었으며, 농도 의존적으로 $\mathrm{NO}$ 발 현을 억제하였다. $\mathrm{LPS}$ 에 의해서 생성된 $\mathrm{PGE}_{2}$ 의 생성억제 효과 를 측정한 결과 $25 \mu \mathrm{g} / \mathrm{mL}$ 의 처리농도에서 ethanol 추출물이 $26.2 \%$ 의 저해율을 나타내었다. NO 생성 억제기작에 관한 iNOS 단백질의 발현량을 측정한 결과 $25 \mu \mathrm{g} / \mathrm{mL}$ 의 농도에서 $40 \%$ 의 높은 억제효과를 나타내었으며, 농도 의존적으로 감소하는 경향 을 관찰 할 수 있었다. LPS 처리시 또 다른 염증인자인 COX2 의 단백질 발현을 측정한 결과 $25 \mu \mathrm{g} / \mathrm{mL}$ 의 처리 농도에서 $64 \%$ 의 저해효과를 나타내었다. 잣나무잎 추출물이 Raw 264.7 세포에서 LPS에 의해서 생성되는 TNF-·, IL-6의 생성억제 효 과를 측정한 결과 $25 \mu \mathrm{g} / \mathrm{mL}$ 의 처리농도에서 각각 $61.7,62 \%$ 의 저해 효과를 나타내었다. 따라서 잣나무잎 추출물은 염증억제를 위한 천연 기능성 소재로 활용이 가능할 것으로 판단되었다.

Keywords 잣나무잎 - 추출물 - 항염증 - Hyaluronidase 억제

감사의 글 이 논문은 2015 년 경북대학교 전임교원 연구년 교수 연구비에 의하여 연구되었음.

\section{References}

Bae BH, Kim YO (2003) Effect of leaf aqueous extracts from some gymnosperm plant on the seed germination, seedling growth and transplant of Hibiscus syriacus varieties. Korean J Ecol 26: 37-47

Bunney S (1992) The illustrated encyclopedia of herbs. Chancellor press. London

Carmichael J, DeGraff WG, Gazdar AF. Minna JD, Mitchell JB (1987) evaluation of a tetrazolium based semiautomated colorimetric assay: assessment of chemosensitivity testing. Cancer Res 47: 936-942

Cheon YP, Mohammad LM, Park CH, Hong JH, Lee GD, Song JC, Kim KS (2009) Bulnesia Sarmienti Aqueous extract inhibits inflammation in LPS-stimulaged Raw 264.7 cells. J of life science 19: 479-485

Cho YJ, An BJ (2008) Anti-inflammatory effect of extracts from Cheongmoknosang (Morus alba L.) in Lipopolysaccharide stimulated Raw cells. J Kor Soc Appl Biol Chem 51: 44-48

Cho YJ, Chun SS, Kwon HJ, Yoon SJ, Lee KH (2005) Comparison of physiological activities between hot-water and ethanol extracts of Bokbunja (Rubus coreanum F.). J Kor Soc Food Sci Nutr 34: 790-796

Cuyckens F, Claeys MJ (2004) Mass spectrometry in the structural analysis of flavonoids. J Mass Spec 39: 1-15

Dorfman A, Ott ML (1948) A turbidimetric method for the assay of hyaluronidase. J Biol Chem 172: 367-375

Ghosh P (1994) The role of hyaluronic acid (hyaluronan) in health and disease: interactions with cells, cartilage and components of synovial fluid. Clin Exp Rheumatol 12: 75-82

Gross SS, Wolin MS (1995) Nitric oxide: pathophysiological mechanisms. Annu Rev Physiol 57: 737-769

Kim JE, Kim WY, Kim JW, Park HS, Lee SH, Lee SY, Kim MJ, Kim AR, Park SN (2010) Antibacterial, atioxidative activity and component analysis of Pinus koraiensis leaf extracts. J Soc Cosmet Scientists Korea 36: 303-314

Kim NK, Kim MH, Yoon CS, Choi SW (2006) Studies on the antiinflammatory activity of paulownia coreana Uyeki leaf extracts. J Soc Cosmet Scientists Korea 32: 241-247

Kroncke KD, Fehsel K, Kolb-Bachofen V (1998) Inducible nitric oxide synthase in human diseases. Clin Exp Immunol 113: 147-156

Lee HJ, Choi YJ, Choi DH, Hong IP (2003) Extractives of Pinus koraiensis wood. Mokchae Konghak 31: 49-56

Lee NH, Lee SJ, Jung DS, Bu HJ, Yang HC, Riu KZ (2001) Screening of the tyrosinase inhibition and hyaluronidase inhibition activities, and radical scavenging effects using plants in Cheju. Kor J Pharmacogn 32: 175180

Moon TC, Park JO, Chung KW, Son KH, Kim HP, Kang SS, Chang HW (1999) Anti-inflammatory activity of the flavonoid components of Lonicera japonica. Yakhak Hoeji 43: 117-123

Naoko K, Satsuki K, Shinichi W (2005) IL-17 suppresses TNF- $\alpha$-induced CCL27 production through induction of COX-2 in human keratinocytes. J Allergy and Clin Immun 116: 1144-1150

Nirupama S, Anil KS, Battu A, Sangita M, Sudip G, Nasreen ZE (2005) Human resistin stimulates the pro-inflammatory cytokines TNF- $\alpha$ and IL-12 in macrophages by NF-Ks-dependent pathway. Biochem and Biophy Res Comm 334: 1092-1101

Oshima H, Bartsch H (1994) Chronic infections and inflammatory processes as cancer risk factors: possible role of nitric oxide in carcinogenesis. Mutat Res 305: 253-264

Park GH, Lee JY, Kim DH, Cho YJ, An BJ (2011) Anti-oxidant and antiinflammatory effects of Rosa multiflora root. J Life Sci 21: 1120-1126

Park SH, Hwang HS, Han JH (2004) Development of drink from composition with medicinal plants and evaluation of its physiological function. Korea J Nutr 37: 364-372

Park SJ, Kim JY, Jang YP, Cho YW, Ahn EM, Baek NI (2007) Inhibition of LPS induced iNOS, COX-2 and cytokines expression by genistein-4'-O- 
$\alpha$-L-rhamnopyranosyl-(1-2)- $\beta$-D-glucopyranoside through the NF- $\mathrm{KB}$ inactivation in Raw 264.7 Cells. Kor J Pharmacogn 38: 339-348

Park SJ, Shin JS, Cho W, Cho YW, Ahn EM, Baek NI (2008) Inhibition of LPS induced iNOS, COX-2 and cytokines expression by kaempferol-3$\mathrm{O}-\beta$-D-sophoroside through the NF- $\mathrm{KB}$ inactivation in RAW 264.7 cells. Kor J Pharmacogn 39: 95-103

So MS, Lee JS, Yi SY (2004) Inhibition of nitric oxide and cytokines in Macrophages by Codonopsis lanceolata. Kor J Food Sci Technol 36: 986-990

Statistical analysis system institute (2001) SAS users guide. Version 8.1. Cary Stuehr DJ (1999) Mammalian nitric oxide synthase. Biochem Biophys Acta
1411: 217-230

Syu-ichi K, Ai S, Ayako T, Takako H, Yu O, Mayuko U, Yutaro O, Norimichi $\mathrm{N}$, Masaaki I (2005) Inhibitory effect of naringin on lipopolysaccharide (LPS)-induced endotoxin shock in mice and nitric oxide production in Raw 264.7 macrophages. Life Sciences 25: 1-9

Won SJ, Park HJ, Lee KT (2008) Inhibition of LPS induced iNOS, COX-2 and cytokines expression by salidroside through the NF-kt inactivation in RAW 264.7 cells. Kor J Pharmacogn 39: 110-117

Yoon WJ, Lee JA, Kim KN, Kim JY, Park SY (2007) In vitro antiinflammatory activity of the Artemisia fukudo extracts in murine macrophage Raw 264.7 cells. Kor J food sci technol 39: 464-469 